\title{
Prevalence of Hearing Loss and Associated Factors in School-Age Individuals in an Urban Area of Northeast Brazil
}

\author{
Aryelly Dayane Silva Nunes ${ }^{1}$ (1) Sheila Andreoli Balen 2,3 () \\ Isabelle Ribeiro Barbosa ${ }^{50}$ \\ 1 Universidade Federal do Rio Grande do Norte, Natal, RN, Brazil \\ 2 Department of Speech, Language and Audiology, Universidade \\ Federal do Rio Grande do Norte, Natal, RN, Brazil \\ 3 Laboratory of Technological Innovation in Health, Hospital \\ Universitário Onofre Lopes, Universidade Federal do Rio Grande do \\ Norte, Natal, RN, Brazil \\ ${ }^{4}$ Department of Collective Health, Universidade Federal do Rio \\ Grande do Norte, Natal, RN, Brazil \\ ${ }^{5}$ Graduate Program in Collective Health, Universidade Federal do Rio \\ Grande do Norte, Natal, RN, Brazil
}

\author{
Dyego Leandro Bezerra Souza4이
}

Int Arch Otorhinolaryngol 2020;24(3):e330-e337.

\begin{abstract}
Address for correspondence Aryelly Dayane da Silva Nunes, PhD student, Department of Odontology, Graduate Program in Collective Health, Universidade Federal do Rio Grande do Norte, Avenida Senador Salgado Filho 1787, Lagoa Nova, Natal-RN, CEP 59010-000, Brazil (e-mail: aryellydayane@gmail.com).
\end{abstract}

Abstract

\section{Keywords}

- hearing loss

- child

- adolescent

- prevalence

- epidemiological factors
Introduction Hearing loss interferes in the development of language and verbal capacities, which causes learning difficulties and deleterious effects.

Objective To analyze the prevalence and associated factors for hearing loss in schoolage individuals of the municipality of Natal, state of Rio Grande do Norte, Northeast Brazil.

Methods Cross-sectional study that evaluated 238 school-age individuals (6-17 years old) in municipal public schools. Meatoscopy was performed and school-age individuals answered the questions "Do you think that you hear well?" and "Do you have earaches?". Auditory evaluation was performed with a Telessaúde audiometer. The responsible adults answered socioeconomic, speech and audiology aspects and risk factors for hearing loss questionnaire.

Results The prevalence of hearing loss was $16 \%$ (11.7-21.4\%); $16 \%$ reported not to hear well, $18.9 \%$ reported earaches, and $26.1 \%$ presented altered meatoscopy. The prevalence of hearing loss was higher in school-age individuals who reported hearing difficulties, in children between the ages of 6 and 12, and with altered meatoscopy results $(p<0.05)$. Airway infection ( $P R=3.37 ; 95 \%$ confidence interval $[\mathrm{Cl}]: 1.48-7.68)$ was found as a risk factor associated with hearing loss, remaining significant in the multivariate model ( $\mathrm{PR}=6.79 ; 95 \% \mathrm{Cl}: 1.98-23.26 ; p=0.002$ ).

Conclusions Hearing loss in this sample is above the values reported in other studies performed in Brazil for this age group. This highlights the necessity of better structure of speech and audiology attention, so that auditory health promotion actions can be systematized for this population. received

May 17, 2019

accepted

October 2, 2019

published online

December 13, 2019
DOI https://doi.org/

10.1055/s-0039-3400507.

ISSN 1809-9777.
Copyright (e) 2020 by Thieme Revinter

Publicações Ltda, Rio de Janeiro, Brazil
License terms

(c) $9 \ominus \$$ 


\section{Introduction}

Hearing is fundamental for the development of speech, language and learning, ${ }^{1}$ as it favors social interaction, acquisition of knowledge and enables the individual to transmit thoughts and feelings, being the basis of the human communication system. $^{2}$ Hearing loss during infancy causes significant impacts, ${ }^{3}$ with repercussions on the economic aspect due to the costs associated with detection and treatment. There are also repercussions on the psychosocial aspect: for the child, the family and the community in general. Hearing loss interferes in the development of language and verbal capacities, which causes learning difficulties and deleterious effects on the emotional, cognitive, academic and social evolution. Compromises in the development of language and school performance depend on when the impairment was acquired, its type, degree and etiology. 4

Hearing losses can result from several causes, ${ }^{5}$ and risk factors for school-age individuals can be otological or nonotological, ${ }^{6}$ such as genetic factors, birth complications, superior airway infections, ${ }^{7}$ middle ear infections, ${ }^{8,9}$ use of specific drugs and exposure to excessive noise. ${ }^{10}$ Studies indicate an effect of social and economic conditions on the prevalence of hearing loss in school-age individuals, such as low socioeconomic levels, ${ }^{11,12}$ income, ${ }^{6,8}$ education levels, ${ }^{13}$ and low maternal education level. ${ }^{14}$

More than $5 \%$ of the world population - 466 million people - present incapacitating hearing loss (432 million adults and 34 million children). It is estimated that, until 2050, more than 900 million people - equivalent to 1 out of 10 people - will suffer incapacitating hearing loss. It is known that $60 \%$ of hearing losses in infancy are due to avoidable causes. $^{10}$

Most people with incapacitating hearing loss live in lowand intermediate- income countries. According to the most recent census performed in Brazil, the presence of selfreported hearing loss in the Brazilian population was 5.1\%, being the $3^{\text {rd }}$ most prevalent loss in the population. The Northeast region of the country, considered one of the poorest regions of Brazil, presents hearing loss prevalence levels above the national average (5.8\%). ${ }^{15}$

Auditory assessment is an attempt to minimize the adverse influence of auditory disorders, and enable the early detection of hearing pathologies, which generally present few symptoms, and are often not noticed or underestimated. ${ }^{7}$ The attention of speech and audiology professionals must be present since birth, in the case of profound sensorineural hearing loss predominance, until the school years, with slight or moderate determined deficits, often due to middle ear infections. $^{5}$

In Brazil, in the year of 2004, the National Policy of Hearing Health Attention ${ }^{16}$ was instituted, with programmed actions directed to the actuation of audiologists in the promotion of health and specific prevention, and to the development of programs promoting hearing health in schools through practices directed to collective and early interventions. However, there are great difficulties to consolidate the policy in Brazil, due to several and diverse questions. The territorial dimension of the country is a hindering factor, along with the cost of equipment, lack of human resources, ${ }^{17}$ and flexibility of the health policy in considering optional hearing screenings in school-age individuals (children and adolescents) but not indicating the instruments to be utilized in the evaluation of auditory acuity in this population. ${ }^{18}$

In the light of the above, there is a clear necessity of developing studies focused on this theme in the Northeast region of Brazil. The objective of the present study was to analyze the prevalence and associated factors for hearing loss in school-age individuals in the municipality of Natal, capital of the state of Rio Grande do Norte, in the epidemiologic study.

\section{Methods}

A cross-sectional study is presented herein, on the evaluation of the prevalence and associated factors for hearing loss in school-age individuals of an elementary municipal public school in Natal. The municipality of Natal is located in the Northeast extreme of Brazil, latitude $5^{\circ} 47^{\prime} 40^{\prime \prime}$ South and longitude $35^{\circ} 12^{\prime} 40^{\prime \prime}$ West. The territorial area is $167.264 \mathrm{~km}^{2}$, with estimated population in 2016 of 877,662 inhabitants. ${ }^{19}$ Life expectancy at birth is 75.08 years and the Municipal Human Development Index (MHDI) was 0.763, in 2010. Regarding education, school life expectancy is $9.85 .^{20}$ The city has 36 districts/neighborhoods and four administrative regions - North, South, East and West. ${ }^{21}$

In Natal, 104,005 students were enrolled in elementary education, of which 35,400 were enrolled in municipal schools, and the remaining in state, federal and private schools. The municipality counts with 16 municipal schools that encompass all grades of elementary education, of which one school is located in the East zone, five in the West, eight in the North and two in the South. ${ }^{22}$

Considering the population of elementary education students of the municipal public education network to be 35,400 students, the prevalence of hearing loss in schoolage individuals was $24.2 \%{ }^{23}$ with a $95 \%$ confidence level, design effect 1.5 , and $15 \%$ non-response rate, resulting in a sample size of 258 students. The sampling procedure was performed per conglomerate in 2 steps: in the first step, 4 schools were drawn, out of the 16 eligible, 1 per district. The second conglomerate was constituted by a draw of participating students, considering stratified sample representation, drawing students from all grades of the allocated schools. Considering a proportionality in the distribution of students in the city districts, the draws selected 29 students from the East zone, 80 students from the West zone, 127 students from the North zone, and 22 students from the South zone. The inclusion criterion was the absence of development syndromes or alterations/disorders that could interfere in the assessment responses.

Data collection was performed between October and December, 2017, by trained and calibrated researchers, and the evaluations were performed by an audiologist with experience in the method, to minimize the risk of bias. Inspection of the external auditory meatus (meatoscopy) was performed utilizing a TK Mikatos (Mikatos, Embu 
das Artes, SP, Brazil) otoscope to check release for hearing screening. The objective was to verify the conditions of hearing screening. It was considered altered when there was accumulation of cerumen. The students answered the questions "Do you think you hear well?" and "Do you have earaches?". The answers "yes" indicates that the individual thinks that can hear well and had earache. Then, using headphones and colloquial language, the students were instructed to raise their hand when they heard the sound, even if in low intensity. Audiometric screening was accomplished in the frequencies of 1,2 and $4 \mathrm{kHz}$, with pass-fail criterion at $20 \mathrm{~dB}^{24}$ In the case of fail for a frequency/ear, the headphones were removed, instructions were repeated and the test was immediately re-taken. ${ }^{24}$ When the final result of the audiometric screening was a failure, the individual was considered with hearing loss to the present study, due the high probability of hearing loss. All of the students who failed and/or had accumulation of cerumen were referred to the local health system. The evaluation environment noise was controlled by the TS measurement, and by an KR438 (Akrom, São Leopoldo, Brazil) sound level meter, registered in $\mathrm{dB} A$, where both presented similar intensities. Before starting the tests, biological calibration was performed with a normal hearing researcher, measured from auditory evaluation in a cabin.

Auditory assessment was accomplished with a Telehealth audiometer (TS). ${ }^{25,26}$ The instrument presents similar results to the conventional audiometer, with clinically equivalent hearing threshold indicating its validity as an instrument for audiological evaluation. TS enables the possibility of registering additional information (regarding location, population under study, environmental noise), and because of the convenience of transportation and use. ${ }^{25,26}$ Software was installed in an Acer Aspire One (Acer, New Taipei City, Taiwan) netbook, and the headphones utilized were Microsoft LifeChat LX-3000 (Microsoft Corporation, Redmond, WA, USA), according to the calibration performed by the software. The aim of the procedure with school-age individuals was to perform a hearing screening, as recommended by the American Academy of Audiology. 24

The adult responsible for the child/adolescent (person with parental responsibility, or the guardian) answered the questionnaire "Brazil economic classification criterion," proposed by the Brazilian Association of Survey Companies (ABEP, in the portuguese acronomy), constituted by three groups of questions, on consumption goods, education level of the head of the household, and public services (water supply, paved roads). The results are analyzed in a ranking, where class A had better economic classification and class DE had worse classifications; in our statistical analysis, we used two categories - classes A, B, C, and a second category with classes D-E. A questionnaire on the possible associated factors was applied to identify the factors associated with hearing loss. The questionnaire included 10 questions on health history and possible signs related to hearing loss.

The questionnaire aimed at determining: (i) age at the date of interview and gender; (ii) history of infections and use of medication; (iii) oral language skills; (iv) written language skills and school performance; (v) family history of hearing disorders, and (vi) habit of using earphones/ headphones and hearing difficulties.

The prevalence of hearing loss was assessed in accordance with the characteristics of the students; the speech and audiology aspects reported by the responsible adults, and the risk indicators for hearing loss as reported by the responsible adults. Descriptive analysis was performed from absolute and relative values, utilizing the chi-squared and Fisher exact tests, with a $5 \%$ significance level.

Bivariate analysis was performed to evaluate the associated factors. The factors that presented $p<0.2$ in the bivariate analysis were included in the multivariate analysis with Poisson regression, using the Wald test for robust estimation. The gender and age group variables were maintained in the final multivariate model for confounding adjustment.

The present study was approved by the Committee of Research Ethics in human beings under the number 73019417.6.0000.5292 on August 29, 2017. All of the participants signed free informed consent and assent forms, according to the Declaration of Helsinki and Resolution $\mathrm{n}^{\circ}$ 466/2012 of the Brazilian National Health Council.

\section{Results}

A total of 258 students regularly enrolled in the schools selected to participate in the study, between the 1st and 9th grades, were invited to participate in the research. There was a loss of $7.75 \%$ of the calculated sample. The prevalence of hearing loss was $16 \%(11.7-21.4 \%)$, while $26.1 \%$ (20.7-32.2\%) presented altered meatoscopy, 16\% (11.7-21.4\%) selfreported hearing difficulties, and $18.9 \%$ (14.3-24.6\%) reported earaches. The average age of the participants was 10.76 years old $( \pm 2.81)$, and $53.4 \%$ were females. There was a significant difference between the results of hearing screening and self-reported earaches, self-reported hearing difficulties, age group, and the result of meatoscopy ( - Table 1 ).

of the 238 school-age individuals included in the research, 167 responsible adults participated in the interview and answered the economic questionnaire; 71 responsible adults did not participate in the interview or answer the questionnaire, and were not found at the school nor returned phone calls, only signed the free informed consent forms. For this sample, there was a significant difference between the results of hearing screening and the self-reported hearing difficulties reported by parents $(p=0.004)$ and the result of the previous hearing screening $(p=0.003)$ (-Table 2$)$.

When analyzing the factors associated with hearing loss, the presence of airway infections reported by the responsible adults ( $\mathrm{PR}=3.37$; 95\% confidence interval $[\mathrm{CI}]$ : $1.48-7.68$ ) was established as an associated factor for hearing loss

\section{(-Table 3).}

In the multivariate model that included the variables gender, age group, airway infections, economic classification, frequency of airway infection, and frequency of earphone/headphone use, only the variable "airway infection" remained significant in the model $(\mathrm{PR}=6.79 ; 95 \% \mathrm{CI}$ : 1.81-25.46; $p=0.004$ ) (-Table 4). 
Table 1 Analysis of the Prevalence of Hearing Loss Regarding Socioeconomic and Speech and Audiology Health Characteristics of School-Age Individuals $(n=238)$

\begin{tabular}{|c|c|c|c|c|}
\hline \multirow[t]{2}{*}{ Variables } & \multirow[t]{2}{*}{ Categories } & \multicolumn{2}{|c|}{ Auditory Screening } & \multirow[t]{2}{*}{ p-value } \\
\hline & & Fail $(n ; \%)$ & Passed $(n ; \%)$ & \\
\hline \multirow[t]{2}{*}{ Self-reported hearing difficulty } & Yes & 25 (12.5\%) & 175 (87.5\%) & \multirow[t]{2}{*}{0.002} \\
\hline & No & 13 (34.2\%) & 25 (65.8\%) & \\
\hline \multirow[t]{2}{*}{ Self-reported earache } & Yes & 14 (31.1\%) & 31 (68.9\%) & \multirow[t]{2}{*}{0.004} \\
\hline & No & $24(12.4 \%)$ & $169(87.6 \%)$ & \\
\hline \multirow[t]{4}{*}{ Location of earache } & Both & $5(45.5 \%)$ & $6(54.5 \%)$ & \multirow[t]{4}{*}{0.006} \\
\hline & Right ear & $5(21.7 \%)$ & $18(78.3 \%)$ & \\
\hline & Left ear & $4(33.3 \%)$ & $8(66.7 \%)$ & \\
\hline & No earache & $24(12.5 \%)$ & $168(87.5 \%)$ & \\
\hline \multirow[t]{2}{*}{ Grade } & Fundamental I & $22(16.7 \%)$ & $110(83.3 \%)$ & \multirow[t]{2}{*}{0.859} \\
\hline & Fundamental II & $16(15.1 \%)$ & $90(84.9 \%)$ & \\
\hline \multirow[t]{2}{*}{ Sex } & Male & $18(16.2 \%)$ & $93(83.8 \%)$ & \multirow[t]{2}{*}{0.922} \\
\hline & Female & $20(15.7 \%)$ & $107(84.3 \%)$ & \\
\hline \multirow[t]{2}{*}{ Age group } & Child (6 to 12 years old) & $32(19.6 \%)$ & $131(80.4 \%)$ & \multirow[t]{2}{*}{0.035} \\
\hline & Adolescent (13 to 18 years old) & $6(8 \%)$ & $69(92 \%)$ & \\
\hline \multirow[t]{2}{*}{ Meatoscopy } & Altered & $13(30.6 \%)$ & $43(69.4 \%)$ & \multirow[t]{2}{*}{0.0004} \\
\hline & Normal & $19(10.8 \%)$ & $157(89.2 \%)$ & \\
\hline \multirow[t]{4}{*}{ School district* } & South zone & $2(9.5 \%)$ & $19(90.5 \%)$ & \multirow[t]{4}{*}{0.129} \\
\hline & East zone & $7(31.8 \%)$ & $15(68.2 \%)$ & \\
\hline & West zone & $9(11.4 \%)$ & $70(88.6 \%)$ & \\
\hline & North zone & $20(17.2 \%)$ & $96(82.8 \%)$ & \\
\hline \multirow[t]{2}{*}{ Economic classification ${ }^{* *}$} & Classes A-B-C & $14(11.8 \%)$ & $105(88.2 \%)$ & \multirow[t]{2}{*}{0.142} \\
\hline & Classes D-E & 10 (20.8\%) & 38 (79.2\%) & \\
\hline
\end{tabular}

Natal/RN, 2017.

*Fisher's Exact test was applied.

${ }^{*} \mathrm{n}=167$.

\section{Discussion}

The prevalence of hearing loss in the sample was high, as well as the number of students that reported hearing difficulties, earaches, and those that presented altered meatoscopy results. Airway infection was associated with hearing loss in the sample.

Research on the prevalence of hearing loss presents different diagnosis methods, different normality criteria, and different age groups. It is possible that these differences are due to educational differences across countries, which consequently leads to differences in the recruitment of students. Studies that used a similar age group found different prevalences: in Canada, the prevalence was $4.7 \%$, established through an association between a $0.5-8 \mathrm{kHz}$ threshold of hearing and otoacoustic emissions; ${ }^{27}$ in Bangladesh, the prevalence was $13 \%$ for incapacitating hearing loss, through $0.5-4 \mathrm{kHz}$ threshold of hearing and otoacoustic emissions. ${ }^{12}$ In studies that utilized the same frequencies in auditory evaluation, ${ }^{28-31}$ the pass-criterion at $20 \mathrm{~dB}$ was not adopted. However, the prevalence found in the present study was still high, compared with previous studies and with prevalence values of $4.92 \%$ in China, ${ }^{30} 2.4 \%$ in Zimbabwe, ${ }^{29} 10.3 \%$ of fails in Poland, ${ }^{31}$ but lower than the $33 \%$ value found in Oman. ${ }^{32}$

Brazilian studies that include children and adolescents use different criteria for evaluation and classification. Two studies that evaluated incapacitating hearing losses found prevalences of $7.1 \%^{33}$ and $3.03 \%{ }^{13}$ However, data presented herein could relate to these studies, as incapacitating loss does not include individuals with discrete and slight loss, for example. Such an inclusion would increase prevalence, such as the value of $16.84 \%$ found in the South region of the country, ${ }^{32}$ similar to that presented herein. Although the studies cited were restricted to the South and Southeast regions, data found for the Northeast region herein are equally alarming, and indicate the necessity of auditory health actions in Brazil for school-age individuals. More studies are also required in the Northeast and other geographic regions, as Brazil presents great territorial dimensions and different habits that, consequently, can produce different associated factors when considering hearing loss in school-age individuals. 
334 Prevalence of Hearing Loss and Associated Factors in School-Age Individuals Nunes et al.

Table 2 Analysis of Hearing Loss Prevalence Regarding Speech and Audiology Characteristics of School-Age Individuals, as Reported by the Responsible Adults $(n=167)$

\begin{tabular}{|c|c|c|c|c|}
\hline \multirow[t]{2}{*}{ Variables } & \multirow[t]{2}{*}{ Categories } & \multicolumn{2}{|c|}{ Auditory Screening } & \multirow[t]{2}{*}{ p-value } \\
\hline & & Passed $(n=24)$ & Fail $(n=143)$ & \\
\hline \multirow[t]{2}{*}{ Hearing difficulty reported by parents } & Yes & $11(9.2 \%)$ & $108(90.8 \%)$ & \multirow[t]{2}{*}{0.004} \\
\hline & No & $13(27.1 \%)$ & $35(72.9 \%)$ & \\
\hline \multirow[t]{2}{*}{ Previous hearing evaluation } & Yes & $06(20.7 \%)$ & $23(79.3 \%)$ & \multirow[t]{2}{*}{0.380} \\
\hline & No & $18(13 \%)$ & $120(87 \%)$ & \\
\hline \multirow[t]{2}{*}{ Result of previous hearing evaluation* } & Altered & $04(80 \%)$ & $01(20 \%)$ & \multirow[t]{2}{*}{0.003} \\
\hline & Normal & $01(5.9 \%)$ & $16(94.1 \%)$ & \\
\hline \multirow[t]{2}{*}{ Reported speech alteration* } & Yes & $02(8.3 \%)$ & $22(91.7 \%)$ & \multirow[t]{2}{*}{0.534} \\
\hline & No & $22(15.4 \%)$ & $121(84.6 \%)$ & \\
\hline \multirow[t]{4}{*}{ Type of reported speech alteration* } & Phonemics/Phonetics & $01(7.7 \%)$ & $12(92.3 \%)$ & \multirow[t]{4}{*}{0.684} \\
\hline & Fluency & $01(25 \%)$ & $03(75 \%)$ & \\
\hline & Other alterations & $0(0 \%)$ & $05(100 \%)$ & \\
\hline & No alterations/Does not know & $22(15.2 \%)$ & $123(84.8 \%)$ & \\
\hline \multirow[t]{2}{*}{ Reported alteration in reading and/or speech } & Yes & $11(16.9 \%)$ & $54(83.1 \%)$ & \multirow[t]{2}{*}{0.501} \\
\hline & No & $13(12.7 \%)$ & $89(87.3 \%)$ & \\
\hline \multirow{4}{*}{$\begin{array}{l}\text { Type of reported alteration in } \\
\text { reading and/or speech* }\end{array}$} & Reading and writing & $02(12.5 \%)$ & $14(87.5 \%)$ & \multirow[t]{4}{*}{0.934} \\
\hline & Reading & $04(16.7 \%)$ & $20(83.3 \%)$ & \\
\hline & Writing & $04(16.7 \%)$ & $20(83.3 \%)$ & \\
\hline & No alterations/Does not know & $14(13.6 \%)$ & $89(86.4 \%)$ & \\
\hline \multirow[t]{2}{*}{ Hearing difficulties in noisy environments } & Yes & $6(18.2 \%)$ & $27(81.8 \%)$ & \multirow[t]{2}{*}{0.579} \\
\hline & No/Does not know & $18(13.4 \%)$ & $116(86.6 \%)$ & \\
\hline
\end{tabular}

Natal/RN, 2017.

*Fisher Exact test was applied.

The protocol "Ear and hearing disorders survey" proposed by the World Health Organization (WHO) performed an investigation on "ear pain" ${ }^{34}$ but it is worth mentioning that the objective of the protocol was wider than only determining the prevalence of hearing loss. Besides, studies of this nature that have followed this protocol ${ }^{13,33,35,36}$ did not present "ear pain/ache" in their results. Among school-age individuals, between the ages of 5 and 14 years old in India, one of the most common ear, nose and throat problem reported was earache, in $8.67 \%$ of the sample, ${ }^{37}$ which was lower than what was presented herein. Research performed with children and adolescents in the USA found that $3.7 \%$ of the sample had suffered an earache in the previous week, and this was an associated factor for hearing loss. ${ }^{38}$ This value was lower than what was presented herein; however, our study did not specify a time period for the earache. This could have been a confounding factor, and the hearing assessment of the $18.9 \%$ who reported earache might not have been influenced by this. However, the information agrees with the association of hearing loss and airway infections as associated factor, and indicates the necessity of further investigation of earache in this age group, such as more effective questioning of the student, which can vary across different cultures.

A study performed in South Africa revealed high prevalence of otoscopy alterations, demonstrating that otoscopy was an economic, fast and reliable measure to identify pathologies in the outer ear. ${ }^{39}$ Among the evaluated students, the occurrence of altered meatoscopy results was higher than the negative screening results, however the findings were correlated. Other studies associated otoscopy with other assessments, such as tympanometry, ${ }^{11}$ audiometric screening, ${ }^{40}$ and tympanometry and pure tone audiometry. ${ }^{41}$ None of these studies included a population of adolescents, which could be justified by the fact that conductive alterations detected during otoscopy/meatoscopy are more common in children. The higher number of children in the sample could have influenced the results, mainly regarding airway infections as risk factors, due to a higher prevalence of conductive alterations in this age group. ${ }^{9}$ Data presented herein corroborates this hypothesis, in function of the higher occurrence of altered meatoscopy results, indicating conductive-type alterations. Other studies found that cerumen was the cause of hearing changes in school-age individuals. ${ }^{9,29}$

The previous hearing evaluation of the students was not associated with the negative result of hearing screening; however, its altered result is associated with fails. This result points beyond the importance of carrying out hearing screenings, as managing health data and previous assessments of this population is also important. In Brazil, periodical screenings are not a national reality. A research that focused on cloud data management indicated that this type of registry enables precise and systematic monitoring of screening programs. ${ }^{30}$ 
Prevalence of Hearing Loss and Associated Factors in School-Age Individuals Nunes et al. 335

Table 3 Prevalence of Hearing Loss and its Associated Factors in School-Age Individuals $(n=167)$

\begin{tabular}{|c|c|c|c|c|c|}
\hline \multirow[t]{2}{*}{ Variables } & \multirow[t]{2}{*}{ Categories } & \multicolumn{2}{|c|}{ Auditory Screening } & \multirow[t]{2}{*}{ p-value } & \multirow[t]{2}{*}{ PR (95\%Cl) } \\
\hline & & Fail $(n ; \%)$ & Pass $(n ; \%)$ & & \\
\hline \multirow[t]{2}{*}{ Age group } & 6 to 12 years old & $19(16.7 \%)$ & $95(83.3 \%)$ & \multirow[t]{2}{*}{0.246} & \multirow[t]{2}{*}{$1.767(0.7-4.48)$} \\
\hline & 13 to 18 years old & $5(9.4 \%)$ & $48(90.6 \%)$ & & \\
\hline \multirow[t]{2}{*}{ Sex } & Male & $11(12.9 \%)$ & $74(87.1 \%)$ & \multirow[t]{2}{*}{0.662} & \multirow[t]{2}{*}{$0.816(0.39-1.72)$} \\
\hline & Female & $13(15.9 \%)$ & $69(84.1 \%)$ & & \\
\hline \multirow[t]{2}{*}{ Economic classification } & Classes A-B-C & $14(11.8 \%)$ & $105(88.2 \%)$ & \multirow[t]{2}{*}{0.147} & \multirow{2}{*}{$\begin{array}{l}1 \\
1.771(0.85-3.71)\end{array}$} \\
\hline & Classes D-E & $10(20.8 \%)$ & $38(79.2 \%)$ & & \\
\hline \multirow[t]{2}{*}{ Airway infections } & Yes & $17(24.3 \%)$ & $53(75.7 \%)$ & \multirow[t]{2}{*}{0.003} & \multirow[t]{2}{*}{$3.37(1.48-7.68)$} \\
\hline & No & $7(7.2 \%)$ & $90(97.8 \%)$ & & \\
\hline \multirow{2}{*}{$\begin{array}{l}\text { Frequency of } \\
\text { airway infections }\end{array}$} & Three or more episodes per year & $13(20.6 \%)$ & $50(79.4 \%)$ & \multirow[t]{2}{*}{0.110} & \multirow[t]{2}{*}{$1.95(0.93-4.09)$} \\
\hline & Up to two episodes per year & $11(10.6 \%)$ & $93(89.4)$ & & \\
\hline \multirow{2}{*}{$\begin{array}{l}\text { Reported use of } \\
\text { earphone/headphone }\end{array}$} & Yes & $10(11.6 \%)$ & $76(88.4 \%)$ & \multirow[t]{2}{*}{0.379} & \multirow[t]{2}{*}{$0.673(0.32-1.43)$} \\
\hline & No & $14(17.3 \%)$ & $67(82.7 \%)$ & & \\
\hline \multirow{3}{*}{$\begin{array}{l}\text { Reported frequency } \\
\text { of the use of } \\
\text { earphone/headphone }\end{array}$} & Does not use/Does not know & $14(17.1)$ & $68(82.9 \%)$ & - & 1 \\
\hline & Rarely & $2(5.4 \%)$ & $35(94.6 \%)$ & 0.118 & $0.317(0.08-1.32)$ \\
\hline & Daily & $8(14.8 \%)$ & $46(85.2 \%)$ & 0.888 & $0.868(0.39-1.93)$ \\
\hline \multirow[t]{2}{*}{ Relative with hearing loss } & Yes & $3(12 \%)$ & $22(88 \%)$ & \multirow[t]{2}{*}{0.714} & \multirow[t]{2}{*}{$0.811(0.26-2.52)$} \\
\hline & No/Does not know & $21(14.8 \%)$ & $121(85.2 \%)$ & & \\
\hline \multirow{3}{*}{$\begin{array}{l}\text { Relationship to the } \\
\text { relative with hearing loss }\end{array}$} & No relatives with hearing loss & $21(15.3 \%)$ & $116(84.7 \%)$ & \multirow[t]{3}{*}{0.772} & 1 \\
\hline & Parents/siblings & $1(12.5 \%)$ & $7(87.5 \%)$ & & $0.815(0.13-5.32)$ \\
\hline & Grandparents/Aunts/Uncles/Cousins & $2(11.8 \%)$ & $15(88.2 \%)$ & & $0.768(0.2-2.99)$ \\
\hline \multirow{2}{*}{$\begin{array}{l}\text { Reported previous } \\
\text { diagnosis } \\
\text { (past medical history) }\end{array}$} & Yes & $3(18.8 \%)$ & $13(81.3 \%)$ & \multirow[t]{2}{*}{0.706} & \multirow[t]{2}{*}{$1.348(0.45-4.03)$} \\
\hline & No & $21(13.9 \%)$ & $130(86.1 \%)$ & & \\
\hline Reported type of & Absence of illnesses & $21(13.9 \%)$ & $130(86.1 \%)$ & 0.555 & 1 \\
\hline $\begin{array}{l}\text { previous diagnosis } \\
\text { (past medical history) }\end{array}$ & Neurological & $1(25 \%)$ & $3(75 \%)$ & & $1.798(0.31-10.98)$ \\
\hline & Others & $2(16.7 \%)$ & $10(83.3 \%)$ & & $1.198(0.32-4.51)$ \\
\hline Periodic use of & Yes & $2(18.2 \%)$ & $9(81.8 \%)$ & 0.660 & $1.289(0.35-4.79)$ \\
\hline medication & No & 22 (14.1\%) & 134 (85.9\%) & & \\
\hline
\end{tabular}

Abbreviation: $\mathrm{Cl}$, confidence interval.

Natal/RN, 2017.

There was no association between the fail result in screening and the age group of the adolescents, in opposition to what was found for children. This result is probably associated with the determination method for hearing loss, which did not include high frequencies. Research with adolescents between 13 and 18 years old found an association between the use of earphones/headphones and threshold of hearing over 20dB in high frequencies. ${ }^{42}$ It is important to consider not only the recommendations but also frequent exposure to elevated levels of sound pressure, common in this age group. ${ }^{43}$ More studies that include hearing thresholds for higher frequencies are therefore necessary.

The lack of structure of the attention network regarding speech and audiology health in Brazil is very evident, especially in the poorest regions of the country. The Brazilian Northeast registers the lowest number of speech and language pathologists and audiologists per capita in the country $(0.73 / 10,000$ inhabitants $) .{ }^{44}$ The Rio Grande do Norte state, situated in the Northeast region, registered one of the highest hearing loss rates of the country $(6.1 \%){ }^{15}$ Rio Grande do Norte is one of the poorest states of Brazil (Human Development Index 0.684, Gini Index 0.524). ${ }^{15}$ For these areas, with lower organization of health services, information on hearing loss in school-age children is useful in the decision-making process within the subject of public health screening, prevention, and auditory rehabilitation. ${ }^{45}$ More specific promotion and prevention measures directed to the auditory health of this population can be subsidized, reducing the negative impacts on development and schooling.

In Latin America, the management of auditory health has not been a historical priority, with more investments in treatment 
Table 4 Multivariate Model by Poisson Regression for the Factors Associated with Hearing Loss in School-Age Individuals ( $n=167)$ in the Municipality of Natal, RN, Brazil

\begin{tabular}{|c|c|c|c|}
\hline Variable & Category & PR (95\%Cl) & p-value* \\
\hline \multirow[t]{2}{*}{ Gender } & Female & \multirow[t]{2}{*}{$1.21(0.53-2.75)$} & \multirow[t]{2}{*}{0.640} \\
\hline & Male & & \\
\hline \multirow[t]{2}{*}{ Age group } & $6-12$ years old & \multirow[t]{2}{*}{$1.43(0.47-4.32)$} & \multirow[t]{2}{*}{0.522} \\
\hline & $13-18$ years old & & \\
\hline \multirow[t]{2}{*}{ Economic classification } & A-B-C & \multirow[t]{2}{*}{$0.91(0.37-2-26)$} & \multirow[t]{2}{*}{0.850} \\
\hline & $\mathrm{D}-\mathrm{E}$ & & \\
\hline \multirow[t]{2}{*}{ Airway infection } & Yes & \multirow[t]{2}{*}{$6.79(1.81-25.46)$} & \multirow[t]{2}{*}{0.004} \\
\hline & No & & \\
\hline \multirow[t]{2}{*}{ Frequency of airway infections } & Up to two episodes per year & \multirow[t]{2}{*}{$0.43(0.13-1.43)$} & \multirow[t]{2}{*}{0.172} \\
\hline & Three or more episodes per year & & \\
\hline \multirow[t]{3}{*}{ Frequency of earphone/headphone use } & Daily & $0.85(0.31-2.32)$ & \multirow[t]{3}{*}{0.509} \\
\hline & Rarely & $0.39(0.07-1.91)$ & \\
\hline & Does not use/Does not know & 1 & \\
\hline
\end{tabular}

Abbreviation: $\mathrm{Cl}$, confidence interval.

Significance Omnibus test $=0,057$.

*Wald test.

than in prevention. ${ }^{46}$ The high prevalence found herein agrees with the studies that indicate that the prevalence of hearing loss is higher in low- and intermediate-income countries, ${ }^{47}$ and indicate socioeconomic factors associated with loss. ${ }^{6,8,11,14,42}$ When investigating ear, nose and throat morbidities in schoolage individuals in India, there was a significant association between the maternal education level and the search for health services directed to school-age individuals. ${ }^{37}$ Herein no specific analysis was performed on schooling, however the education level of the head of household was considered in the economic evaluation proposed by the ABEP. Homogeneity of the sample regarding economic classes could have influenced the result of the association between economic classification and prevalence of hearing loss. Sample loss could also have influenced this and other aspects that did not present association. Due to this limitation and to local characteristics, new studies are suggested on the factors associated with hearing loss in schoolage individuals, with a broader classification of the specific characteristics of children and adolescents age groups.

\section{Conclusion}

The sample studied herein presented a high prevalence of hearing loss as well as airway infections as risk factors. This information provides data for actions directed to hearing health and prevention of loss in school-age individuals in the studied capital, which can be extrapolated to the state and to other locations with similar characteristics.

\section{Funding}

The present work was supported by the Coordination of Improvement of Higher Level Personnel - Brasil (CAPES) under grant 001.
Conflict of Interests

The authors declare that have no conflict of interests.

\section{References}

1 Regaçone SF, Gução ACB, Frizzo ACF. Eletrofisiologia: perspectivas atuais de sua aplicação clínica em fonoaudiologia. Verba Volant. 2003;1:1-20

2 Northern JL, Downs MP. Audição e perda auditiva em crianças. In: Audição na infância. $5^{a}$ ed. Rio de Janeiro: Guanabara Koogan S.A.; 2005:3-28

3 Vasconcelos RM, Monte MO, Aragão VMF, Silva BT. Alterações auditivas em crianças de 7 a 9 anos de idade de uma escola pública de ensino fundamental em São Luís, Maranhão. RBPS 2007;20 (03):155-160. Doi: 10.5020/18061230.2007

4 Speri MRB. A criança com deficiência auditiva: da suspeita ao processo de reabilitação fonoaudiológica. Verba Volant. 2013;4(01):40-64

5 Vieira ABC, Macedo LR, Gonçalves DUO. Diagnóstico da perda auditiva na infância. Pediatria (Napoli) 2007;29(01):43-49

6 Czechowicz JA, Messner AH, Alarcon-Matutti E, et al. Hearing impairment and poverty: the epidemiology of ear disease in Peruvian schoolchildren. Otolaryngol Head Neck Surg 2010;142 (02):272-277. Doi: 10.1016/j.otohns.2009.10.040

7 Gierek T, Gwóźdź-Jezierska M, Markowski J, Witkowska M. The assessment of hearing organ of school children in Upper Silesia region. Int J Pediatr Otorhinolaryngol 2009;73(12):1644-1649. Doi: $10.1016 /$ j.ijporl.2009.08.009

8 Shargorodsky J, Curhan SG, Curhan GC, Eavey R. Change in prevalence of hearing loss in US adolescents. JAMA 2010;304 (07):772-778. Doi: 10.1001/jama.2010.1124

9 Al-Rowaily MA, AlFayez AI, AlJomiey MS, AlBadr AM, Abolfotouh MA. Hearing impairments among Saudi preschool children. Int J Pediatr Otorhinolaryngol 2012;76(11):1674-1677. Doi: 10.1016/ j.ijporl.2012.08.004

10 Deafness and hearing loss [Internet]. WHO: World Health Organization, 2018. Available at: http://www.who.int/en/news-room/factsheets/detail/deafness-and-hearing-loss. Accessed May 20, 2018 
11 Taha AA, Pratt SR, Farahat TM, et al. Prevalence and risk factors of hearing impairment among primary-school children in Shebin Elkom District, Egypt. Am J Audiol 2010;19(01):46-60. Doi: 10.1044/1059-0889(2010/09-0030)

12 Tarafder KH, Akhtar N, Zaman MM, Rasel MA, Bhuiyan MR, Datta PG. Disabling hearing impairment in the Bangladeshi population. J Laryngol Otol 2015;129(02):126-135. Doi: 10.1017/S00222151 1400348X

13 Baraky LR, Bento RF, Raposo NR, et al. Disabling hearing loss prevalence in Juiz de Fora, Brazil. Rev Bras Otorrinolaringol (Engl Ed) 2012;78(04):52-58. Doi: 10.1590/S1808-86942012000400011

14 le Clercq CMP, van Ingen G, Ruytjens L, et al. Prevalence of Hearing Loss Among Children 9 to 11 Years Old: The Generation R Study. JAMA Otolaryngol Head Neck Surg 2017;143(09):928-934. Doi: 10.1001/jamaoto.2017.1068

15 IBGE, Instituto Brasileiro de Geografia e Estatística. Censo Demográfico 2010: resultados gerais da amostra. Censo Demogr. Rio de Janeiro: 57-63. ISSN 0104-3145.

16 Brasil, Presidência da República, Casa Civil, Subchefia para Assuntos Jurídicos. Portaria ${ }^{\circ} 2.073 / \mathrm{gm}$, de 28 de novembro de 2004 . Institui a Política Nacional de Atenção à Saúde Auditiva. Available at: http:// www.saude.mg.gov.br/index.php?option=com_gmg\&controller $=$ document\&id=814. Accessed Jul 20, 2018.

17 Samelli AG, Rabelo CM, Vespasiano AP. Development and analysis of a low-cost screening tool to identify and classify hearing loss in children: a proposal for developing countries. Clinics (São Paulo) 2011;66(11):1943-1948. Doi: 10.1590/S1807-59322011001100015

18 Brasil, Ministério da Saúde. Caderno do gestor do PSE / Ministério da Saúde, Ministério da Educação. Brasília: Ministério da Saúde; 2015

19 IBGE, Instituto Brasileiro de Geografia e Estatística. Matrícula, ensino fundamental, escola pública municipal, 2015 [Internet]. Available at: https://cidades.ibge.gov.br/brasil/rn/natal/pesquisa/ 13/78117. Acessed Nov 09, 2019

20 PNUD - Programa Das Nações Unidas Para O Desenvolvimento. Atlas de desenvolvimento humano do Brasil de 2013 [Internet]. Instituto de Pesquisa Econômica e Aplicada; Fundação João Pinheiro. 2013. Available at: http://www.atlasbrasil.org.br/2013/. Accessed may 21, 2018.

21 Nunes DSSNN, Lopes F Junior, Tavares E, et al. Anuário Natal 2016. Natal: SEMURB; 2016

22 SME. Secretaria Municipal de Educação Prefeitura Municipal do Natal. Boletim Estatístico Censo Escolar 2015. Assessoria de Planejamento e Avaliação; 2015

23 Balen SA. Programa de Saúde Auditiva do Escolar: etapa de identificação, diagnóstico e acompanhamento. Ação de extensão. Departamento de Fonoaudiologia. Universidade Federal do Rio Grande do Norte; 2013

24 Childhood Hearing Screening Guidelines. [Internet] American Academy of Audiology: 2011. Available at: http://www.cdc.gov/ncbddd/ hearingloss/documents/aaa_childhood-hearing-guidelines_2011. pdf. Accessed August 16, 2017.

25 Lopez E. Audiómetro de screening de bajo costo para el diagnóstico precoz y la prevención de la hipoacusia. [dissertation] Maestría en Ingenieria Biomedica, Argentina: Universidad Favaloro, 2010:90

26 Ferrari DV, Lopez EA, Lopes AC, Aiello CP, Jokura PR. Results obtained with a low cost software-based audiometer for hearing screening. Int Arch Otorhinolaryngol 2013;17(03):257-264. Doi: 10.7162/S1809-97772013000300005

27 Feder KP, Michaud D, McNamee J, Fitzpatrick E, Ramage-Morin P, Beauregard Y. Prevalence of Hearing Loss Among a Representative Sample of Canadian Children and Adolescents, 3 to 19 Years of Age. Ear Hear 2017;38(01):7-20. Doi: 10.1097/AUD.0000000000000345

$28 \mathrm{Al}$ Khabori M, Khandekar R. The prevalence and causes of hearing impairment in Oman: a community-based cross-sectional study. Int J Audiol 2004;43(08):486-492. Doi: 10.1080/14992020400050062

29 Westerberg BD, Skowronski DM, Stewart IF, Stewart L, Bernauer M, Mudarikwa L. Prevalence of hearing loss in primary school children in Zimbabwe. Int J Pediatr Otorhinolaryngol 2005;69 (04):517-525. Doi: 10.1016/j.ijporl.2004.11.020

30 Kam AC, Gao H, Li LK, Zhao H, Qiu S, Tong MC. Automated hearing screening for children: A pilot study in China. Int J Audiol 2013;52 (12):855-860. Doi: 10.3109/14992027.2013.832419

31 Skarzyński PH, Świerniak W, Piłka A, et al. A Hearing Screening Program for Children in Primary Schools in Tajikistan: A Telemedicine Model. Med Sci Monit 2016;22:2424-2430. Doi: 10.12659/MSM.895967

32 Balen SA, Debiasi TF, Pagnossim DF, Broca VS, Roggia SM, Gondim LM. Caracterização da Audição de Crianças em um Estudo de Base Populacional no Município de Itajaí / SC. Int Arch Otorhinolaryngol 2009;4:372-380

33 Béria JU, Raymann BC, Gigante LP, et al. Hearing impairment and socioeconomic factors: a population-based survey of an urban locality in southern Brazil. Rev Panam Salud Publica 2007;21(06):381-387

34 World Health Organization. Ear and Hearing Disorders Examination Form. Prevention of blindness and deafness: 2012

35 Gondim LM, Balen SA, Zimmermann KJ, Pagnossin DF, Fialho IdeM, Roggia SM. Study of the prevalence of impaired hearing and its determinants in the city of Itajaí, Santa Catarina State, Brazil. Rev Bras Otorrinolaringol (Engl Ed) 2012;78(02):27-34. Doi: $10.1590 /$ S1808-86942012000200006

36 Ramma L, Sebothoma B. The prevalence of hearing impairment within the Cape Town Metropolitan area. S Afr J Commun Disord 2016;63(01):a105. Doi: 10.4102/sajcd.v63i1.105

37 Shah V, Lodha N, Patel B, et al. Assessment of Ear Nose and Throat morbidities prevalent in the school going children aged 5-14 years in rural area of Jamnagar. J Res Med Den Sci. 2014;2(04): 71-74. Doi: 10.5455/jrmds.20142414

38 Niskar AS, Kieszak SM, Holmes A, Esteban E, Rubin C, Brody DJ. Prevalence of hearing loss among children 6 to 19 years of age: the Third National Health and Nutrition Examination Survey. JAMA 1998;279(14):1071-1075

39 Phanguphangu MC. Otoscopic examinations reveal high prevalence of outer and middle ear pathologies in paediatrics in Limpopo, South Africa. Int J Audiol 2017;56(04):215-218. Doi: 10.1080/14992027.2016.1244868

40 Wake M, Tobin S, Cone-Wesson B, et al. Slight/mild sensorineural hearing loss in children. Pediatrics 2006;118(05):1842-1851. Doi: $10.1542 /$ peds.2005-3168

41 Govender S, Latiff N, Asmal N, Ramsaroop S, Mbele T. Evaluating the outcomes of a hearing screening service for grade one learners in urban areas at Durban, South Africa. J Public Health Africa 2015;6(01):529. Doi: 10.4081/jphia.2015.529

42 Hong SM, Park I-S, Kim YB, Hong SJ, Lee B. Analysis of the Prevalence of and Factors Associated with Hearing Loss in Korean Adolescents. PLoS One 2016;11(08):e0159981. Doi: 10.1371/journal.pone.0159981

43 Marques APC, Filho ALM, Monteiro GTR. Prevalence of hearing loss in adolescents and young adults as a result of social noise exposure: meta-analysis. Rev CEFAC 2015;17(06):2056-2064. Doi: 10.1590/1982-021620151761115

44 Santos JAP, Arce VAR, Magno LD, Ferrite S. Provision of Speech, Language and Hearing services in the public municipal healthcare network in the state capitals of Northeast Brazil. Audiol Commun Res 2017;22:e1665. Doi: 10.1590/2317-6431-20151665

45 Jun HJ, Hwang SY, Lee SH, Lee JE, Song JJ, Chae S. The prevalence of hearing loss in South Korea: data from a population-based study. Laryngoscope 2015;125(03):690-694. Doi: 10.1002/lary.24913

46 Madriz JJ. Audiology in Latin America: hearing impairment, resources and services. Scand Audiol Suppl 2001;53(53):85-92

47 Stevens G, Flaxman S, Brunskill E, Mascarenhas M, Mathers CD, Finucane M; Global Burden of Disease Hearing Loss Expert Group. Global and regional hearing impairment prevalence: an analysis of 42 studies in 29 countries. Eur J Public Health 2013;23(01): 146-152. Doi: 10.1093/eurpub/ckr176 